\title{
Pomological Characteristics and Ploidy Levels of Japanese Plum (Prunus salicina Lindl.) Cultivars Preserved in Poland
}

\author{
Agnieszka Głowacka (D), Mirosław Sitarek*D, Elżbieta Rozpara (D) and Małgorzata Podwyszyńska (D) \\ The National Institute of Horticultural Research, ul. Konstytucji 3 Maja 1/3, 96-100 Skierniewice, Poland; \\ agnieszka.glowacka@inhort.pl (A.G.); elzbieta.rozpara@inhort.pl (E.R.); \\ malgorzata.podwyszynska@inhort.pl (M.P.) \\ * Correspondence: miroslaw.sitarek@inhort.pl; Tel.: +48-46-834-54-39
}

Citation: Głowacka, A.; Sitarek, M.; Rozpara, E.; Podwyszyńska, M. Pomological Characteristics and Ploidy Levels of Japanese Plum (Prunus salicina Lindl.) Cultivars Preserved in Poland. Plants 2021, 10, 884. https://doi.org/10.3390/ plants10050884

Academic Editor: Gunārs Lācis

Received: 31 March 2021

Accepted: 23 April 2021

Published: 27 April 2021

Publisher's Note: MDPI stays neutral with regard to jurisdictional claims in published maps and institutional affiliations.

Copyright: (C) 2021 by the authors. Licensee MDPI, Basel, Switzerland. This article is an open access article distributed under the terms and conditions of the Creative Commons Attribution (CC BY) license (https:// creativecommons.org/licenses/by/ $4.0 /)$.

\begin{abstract}
Research on the resistance to frost, susceptibility to sharka, flowering biology, fruit setting, yield, and ploidy levels of 36 Japanese plum cultivars (mostly hybrids of Prunus salicina with Prunus cerasifera) were carried out in 2015-2020 at the Experimental Orchard located in Dabrowice near Skierniewice. Relatively mild winters with sporadic temperature drops to nearly $-21^{\circ} \mathrm{C}$ in January of 2017 and 2018 caused slight damage to several cultivars of Japanese plum insufficiently resistant to frost. The trees of most cultivars remained healthy, with no signs of damage. 'Barkhatnaya' and 'Tatyana' cultivars turned out to be very susceptible to sharka. 'Herkules' trees were the most vigorous. 'Barkhatnaja', 'Blue Gigant', 'Shater', and 'Tatyana' trees were characterized by weak growth. The trees of Japanese plum started flowering early, usually in the first or second decade of April. Most of the cultivars belonged to early season cultivars, the fruits of which ripened in July. Based on the assessment of tree productivity, 'Barkhatnaya', 'Inese', 'Shater', 'Tatyana', and 'Vanier' are the best for growing in the climate of Central Europe. 'Tsernushka', 'Chuk', 'Dofi Sandra', 'Early Golden', 'Ewierch Rannyj', 'Yevraziya', 'Gek', 'General', 'Kometa', 'Kometa Late', 'Maschenka', and 'Naidyona' trees also yielded well. 'Blue Gigant', 'Black Amber', and 'Herkules' had the largest fruits, and 'Chuk' and 'Inese' cultivars produced the smallest fruits. Among the assessed Japanese plum cultivars, those with round fruit, dark skin with various shades of purple, yellow flesh, and A cytometric analysis showed that almost all cultivars are diploid, except for 'Herkules' (possibly pentaploid) and 'Yevraziya' (possibly hexaploid or aneuploid).
\end{abstract}

Keywords: Prunus salicina Lindl.; gene bank; cultivars; yield; fruit quality; sharka; ploidy level

\section{Introduction}

The genus Prunus, which belongs to the Rosaceae family, includes over 35 species that are native to Europe, Asia, and America [1-3]. The basic chromosome number in Prunus is $\mathrm{x}=8$ [4]. The somatic chromosome number of various Prunus species varies from diploid to hexaploid [4-7]. Most of the species are diploid $(2 \mathrm{n}=2 \mathrm{x}=16)$, e.g., P. armeniaca, P. avium, $P$. canescens, $P$. cerasifera, $P$. mahaleb, P. persica, P. spinosa, and P. tomentosa. There are also several tetraploids $(2 \mathrm{n}=4 \mathrm{x}=32)$, such as $P$. cerasus, $P$. fruticosa, and $P$. maackii, and hexaploids $(2 \mathrm{n}=6 \mathrm{x}=48)$, such as $P$. domestica and $P$. domestica var. insititia. Although $P$. salicina is generally considered to be diploid [5,6], tetraploids have also been recorded in this species [4].

Two types of plum dominate in the world of commercial cultivation. One type is European plums (Prunus domestica L.) and the second is Japanese plums (Prunus salicina Lindl.) [2,3]. Almost all of the plum cultivars grown in Poland in commercial orchards belong to $P$. domestica. and their cultivation has a long tradition [8,9]. European plum trees start bearing fruit early, and most cultivars yield abundantly and annually.

Japanese plums (P. salicina) are characterized by their high abundance and variability when compared to other tree crops. Japanese plum trees differ from European plum trees in terms of many morphological features, and the fruits are distinguished by size, aroma, color 
of the skin, and fruit storage capacity [1,3]. Japanese plum cultivars spread to cultivation in the USA thanks to a breeding program initiated in 1875 by Luther Burbank $[3,10]$. Later, cultivars resulted from crosses between P. salicina and American plum (Prunus americana Marsh.). They were characterized by increased frost resistance and became common in production. The Japanese plum reached Europe later than the USA and it spread mainly in the Mediterranean countries. In countries of Central and Northeast Europe, interest in this plum was lower due to less favorable climatic conditions. However, in recent decades, the situation has changed due to the gradual warming of the climate and progress in breeding of new cultivars with very attractive fruit and relatively late flowering of trees, which are less exposed to spring frosts. Most of these cultivars result from hybridization between $P$. salicina and either P. cerasifera or American plum cultivars. The first Japanese plum trees were brought for testing to The National Institute of Horticultural Research in Skierniewice in the 1970s from Hungary. Because of higher thermal requirements than European plum cultivars and, above all, the very early beginning of vegetation, at that time their flowers were freezing, and the trees either did not bear fruit at all or yield was far from what was expected [8].

The results of research that was carried out in the plum collection at the Experimental Orchard in Dabrowice show that, in recent years, many Japanese plum cultivars have yielded similarly to those of the European plum (P. domestica). This article presents an assessment of agronomic value and ploidy levels of 36 Japanese plum cultivars in the climatic conditions of central Poland.

\section{Results and Discussion}

\subsection{Cold Hardiness}

In 2015-2020, the winters were relatively mild. The lowest temperatures with occasional drops to nearly minus $21^{\circ} \mathrm{C}$ were recorded in 2017 and 2018. They only caused slight damage to trees of several Japanese plum cultivars, insufficient resistant to frost. Trees of most cultivars remained healthy, with no signs of damage (Table 1). In the analyzed period, winter 2019/2020 was exceptionally warm for this latitude. The lowest temperature was recorded in January, but it was only $-4.6^{\circ} \mathrm{C}$. Such conditions meant that trees of three cultivars with a short dormancy period, 'Formosa', 'Gek', and 'Dofi Sandra', started flowering at the end of January. This is a very unfavorable phenomenon, because trees are damaged by subsequent cold periods during winter and early spring, as previously reported by Grzyb and Rozpara [8].

Table 1. Health status of 36 P. salicina cultivars that were grafted on 'Wangenheim Prune' seedlings.

\begin{tabular}{|c|c|c|c|c|}
\hline \multirow{2}{*}{ Cultivar. } & \multirow{2}{*}{$\begin{array}{l}\text { Frost Damage } \\
\text { to the Trees * }\end{array}$} & \multirow{2}{*}{ Dead Trees } & \multicolumn{2}{|c|}{ Symptoms of Plum pox Virus } \\
\hline & & & On the Leaves ** & On the Fruits *** \\
\hline Angeleno & 9 & 0 & 0 & 0 \\
\hline Barkhatnaya & 9 & 3 & 3 & 3 \\
\hline Black Amber & 7 & 1 & 0 & 0 \\
\hline Black Diamond & 9 & 1 & 0 & 0 \\
\hline Blue Gigant & 7 & 0 & 0 & 0 \\
\hline Chuk & 7 & 0 & 0 & 0 \\
\hline $\begin{array}{l}\text { Desertnaya } \\
\text { Rannaya }\end{array}$ & 9 & 1 & 0 & 0 \\
\hline Dofi Sandra & 7 & 1 & 3 & 0 \\
\hline Early Golden & 7 & 2 & 2 & 2 \\
\hline Ewierch Rannyj & 9 & 1 & 0 & 0 \\
\hline
\end{tabular}


Table 1. Cont.

\begin{tabular}{|c|c|c|c|c|}
\hline \multirow{2}{*}{ Cultivar. } & \multirow{2}{*}{$\begin{array}{l}\text { Frost Damage } \\
\text { to the Trees * }\end{array}$} & \multirow{2}{*}{ Dead Trees } & \multicolumn{2}{|c|}{ Symptoms of Plum pox Virus } \\
\hline & & & On the Leaves ** & On the Fruits *** \\
\hline Friar & 7 & 1 & 0 & 0 \\
\hline Formosa & 7 & 0 & 0 & 0 \\
\hline Gauota & 7 & 1 & 0 & 0 \\
\hline Gek & 9 & 0 & 0 & 0 \\
\hline General & 9 & 0 & 0 & 0 \\
\hline Herkules & 9 & 1 & 1 & 1 \\
\hline Inese & 9 & 0 & 0 & 0 \\
\hline Kometa & 9 & 2 & 0 & 0 \\
\hline Kometa Late & 9 & 0 & 0 & 0 \\
\hline Maschenka & 9 & 1 & 0 & 0 \\
\hline Naidyona & 9 & 0 & 0 & 0 \\
\hline Obilnaya & 7 & 0 & 0 & 0 \\
\hline Oishi Wase & 9 & 1 & 0 & 0 \\
\hline Ozark Premier & 9 & 1 & 0 & 0 \\
\hline Puteshestvennitsa & 9 & 0 & 0 & 0 \\
\hline Santa Rosa & 9 & 0 & 0 & 0 \\
\hline Shater & 7 & 0 & 0 & 0 \\
\hline Shiro & 9 & 0 & 0 & 0 \\
\hline Skoroplodnaya & 9 & 1 & 1 & 0 \\
\hline Slivovidnaya & 9 & 1 & 0 & 0 \\
\hline Superior & 7 & 2 & 0 & 0 \\
\hline Tatyana & 9 & 3 & 3 & 3 \\
\hline Tsernushka & 9 & 0 & 0 & 0 \\
\hline $\begin{array}{l}\text { Tsernushka } \\
\text { Rannaya }\end{array}$ & 9 & 0 & 0 & 0 \\
\hline Vanier & 9 & 1 & 0 & 0 \\
\hline Yevraziya & 9 & 0 & 0 & 0 \\
\hline
\end{tabular}

* Frost damage to trees-assessed on a 1-9-point rating scale: 1-withering or withered trees; 3-trees with extensive damage, individual limbs withering, bark on the trunks and limbs heavily cracked and flaking in large patches, and symptoms of the leaves becoming smaller, yellowing and falling off; 5-trees with clear symptoms of damage, withering annual shoots, large spots of discoloured bark, cracked bark peeling and falling off in small patches, symptoms of the leaves becoming smaller, yellowing and falling off; 7-trees with minor injuries, a few small discolorations of the bark on the shoots and signs of the leaves yellowing; 9-no symptoms; ** Symptoms of Plum pox virus on the leaves assessed on a 1-3-point rating scale: 0-no symptoms; 1 -symptoms on one branch 2 -symptoms on several skeleton branches; 3 -symptoms manifested overall; *** Symptoms of Plum pox virus on the fruits assessed on a 1-3-point rating scale: 0-no symptoms, 1-superficial symptoms without deterioration of the fruit quality; 2 -to $10 \%$ of the fruit with sharka symptoms, fruit abscission and low quality for consumption; $3-$ over $10 \%$ of fruits with pathological changes.

\subsection{Susceptibility to Plum pox Virus (Sharka)}

Sharka is one of the most dangerous plum diseases, which limits the plum cultivation in Europe, including Poland [11,12]. Among the 36 Japanese plum cultivars that were assessed in the experiment, the strongest symptoms of this disease were observed on trees and fruits of 'Barkhatnaya' and 'Tatyana' cultivars (Table 1). Sharka also appeared on 'Dofi Sandra', 'Early Golden', 'Herkules', and 'Skoroplodnaya' trees. Its symptoms were mainly observed on leaves, but, in the case of 'Early Golden' and 'Herkules' cultivars, they 
also appeared on fruits (Table 1). In the available literature, there is no information on the susceptibility to sharka of the above-mentioned Japanese plum cultivars.

\subsection{Tree Vigour}

The observations that were carried out in 2015-2020 showed that, in the collection orchard, 'Herkules' plum trees had the strongest growth (Table 2). Trees of fifteen out of thirty-six assessed cultivars grew strongly, sixteen cultivars were characterized by moderate growth, and the remaining four-by weak growth. The most of Japanese plum cultivars were dominated by a spreading canopy. 'Black Amber', 'Blue Gigant', 'Gauota', and 'Herkules' trees had an upright habit, and 'Dofi Sandra', 'Naidyona', 'Skoroplodnaya', and 'Vanier' were conical (Table 2).

Table 2. Pomological characteristics and productivity of 36 P. salicina cultivars (average, 2015-2020).

\begin{tabular}{|c|c|c|c|c|c|c|c|c|c|}
\hline \multirow{2}{*}{ Cultivar } & \multirow{2}{*}{$\begin{array}{l}\text { Growth } \\
\text { Vigour * }\end{array}$} & \multirow{2}{*}{$\begin{array}{l}\text { Crown } \\
\text { Habit ** }\end{array}$} & \multicolumn{3}{|c|}{ Date of Flowering } & \multirow{2}{*}{$\begin{array}{c}\text { Duration of } \\
\text { Flowering } \\
\text { (days) }\end{array}$} & \multirow{2}{*}{$\begin{array}{l}\text { Beginning of } \\
\text { Fruiting (Year } \\
\text { after Planting) }\end{array}$} & \multirow{2}{*}{$\underset{* * *}{\text { Productivity }}$} & \multirow{2}{*}{$\begin{array}{l}\text { Time of } \\
\text { Harvest }\end{array}$} \\
\hline & & & Start & Full & End & & & & \\
\hline Angeleno & 7 & 7 & 12.04 & 14.04 & 22.04 & 8.5 & 2 & 4.2 & b. $X$ \\
\hline Barkhatnaya & 3 & 7 & 05.04 & 07.04 & 15.04 & 9.3 & 1 & 9 & b. VIII \\
\hline Black Amber & 5 & 3 & 12.04 & 14.04 & 23.04 & 11.7 & 1 & 4.6 & b. IX \\
\hline $\begin{array}{c}\text { Black } \\
\text { Diamond }\end{array}$ & 5 & 7 & 11.04 & 13.04 & 20.04 & 12.3 & 2 & 3.8 & $\begin{array}{l}\text { II dec. } \\
\text { VIII }\end{array}$ \\
\hline Blue Gigant & 3 & 3 & 12.04 & 13.04 & 23.04 & 11.0 & 3 & 3.5 & $\begin{array}{l}\text { II dec. } \\
\text { VIII }\end{array}$ \\
\hline Chuk & 5 & 7 & 04.04 & 06.04 & 12.04 & 10.0 & 2 & 8.5 & e. VII \\
\hline $\begin{array}{l}\text { Desertnaya } \\
\text { Rannaya }\end{array}$ & 7 & 7 & 06.04 & 08.04 & 19.04 & 10.7 & 1 & 5 & e. VII \\
\hline Dofi Sandra & 7 & 5 & 06.04 & 08.04 & 19.04 & 10.0 & 2 & 8 & e. VII \\
\hline Early Golden & 5 & 7 & 11.04 & 13.04 & 23.04 & 10.8 & 1 & 8 & b. VIII \\
\hline $\begin{array}{l}\text { Ewierch } \\
\text { Rannyj }\end{array}$ & 7 & 7 & 10.04 & 12.04 & 19.04 & 9.0 & 2 & 7 & b. VII \\
\hline Friar & 5 & 7 & 12.04 & 14.04 & 23.04 & 11.7 & 2 & 4 & e. IX \\
\hline Formosa & 7 & 7 & 08.04 & 11.04 & 19.04 & 9.0 & 2 & 2.3 & b. VIII \\
\hline Gauota & 5 & 3 & 11.04 & 13.04 & 21.04 & 10.0 & 2 & 5 & b. VII \\
\hline Gek & 5 & 7 & 13.04 & 15.04 & 25.04 & 9.7 & 1 & 7.5 & e. VII \\
\hline General & 7 & 7 & 06.04 & 09.04 & 21.04 & 14.3 & 1 & 7 & e. VII \\
\hline Herkules & 9 & 3 & 12.04 & 14.04 & 23.04 & 8.7 & 1 & 3.3 & $\begin{array}{l}\text { II dec. } \\
\text { VIII }\end{array}$ \\
\hline Inese & 7 & 7 & 11.04 & 13.04 & 19.04 & 9.3 & 1 & 9 & b. VIII \\
\hline Kometa & 5 & 7 & 11.04 & 13.04 & 21.04 & 10.3 & 1 & 7.5 & e. VII \\
\hline Kometa Late & 5 & 7 & 10.04 & 12.04 & 24.04 & 13.0 & 1 & 7.5 & b. VIII \\
\hline Maschenka & 7 & 7 & 10.04 & 12.04 & 22.04 & $11 ., 3$ & 1 & 7 & $\begin{array}{l}\text { II dec. } \\
\text { VII }\end{array}$ \\
\hline Naidyona & 5 & 5 & 10.04 & 12.04 & 19.04 & 8.0 & 2 & 7 & e. VII \\
\hline Obilnaya & 5 & 7 & 08.04 & 10.04 & 21.04 & 10.7 & 1 & 5 & e. VII \\
\hline Oishi Wase & 5 & 7 & 08.04 & 10.04 & 16.04 & 10.0 & 1 & 4.3 & b. VII \\
\hline $\begin{array}{l}\text { Ozark } \\
\text { Premier }\end{array}$ & 5 & 7 & 08.04 & 10.04 & 16.04 & 9.0 & 1 & 6 & b. VIII \\
\hline Puteshestvennitsa & 7 & 7 & 10.04 & 12.04 & 21.04 & 11.3 & 1 & 6.5 & $\begin{array}{l}\text { II dec. } \\
\text { VII }\end{array}$ \\
\hline Santa Rosa & 7 & 7 & 09.04 & 11.04 & 22.04 & 11.7 & 1 & 6 & $\begin{array}{l}\text { II dec. } \\
\text { VII }\end{array}$ \\
\hline Shater & 3 & 7 & 08.04 & 10.04 & 21.04 & 11.3 & 1 & 9 & $\begin{array}{l}\text { II dec. } \\
\text { VII }\end{array}$ \\
\hline Shiro & 7 & 7 & 11.04 & 13.04 & 25.04 & 12.7 & 1 & 6 & b. VIII \\
\hline Skoroplodnaya & 5 & 5 & 11.04 & 13.04 & 21.04 & 8.0 & 2 & 5 & $\begin{array}{l}\text { II dec. } \\
\text { VII }\end{array}$ \\
\hline Slivovidnaya & 7 & 7 & 11.04 & 13.04 & 22.04 & 11.3 & 2 & 6 & e. VII \\
\hline Superior & 5 & 7 & 11.04 & 13.04 & 19.04 & 9.3 & 1 & 6 & $\begin{array}{l}\text { II dec. } \\
\text { VIII }\end{array}$ \\
\hline Tatyana & 3 & 7 & 04.04 & 07.04 & 16.04 & 12.0 & 1 & 9 & b. VIII \\
\hline Tsernushka & 7 & 7 & 06.04 & 08.04 & 19.04 & 11.6 & 1 & 8 & b. VII \\
\hline $\begin{array}{c}\text { Tsernushka } \\
\text { Rannaya }\end{array}$ & 7 & 7 & 05.04 & 07.04 & 14.04 & 9.7 & 2 & 7.9 & b. VII \\
\hline Vanier & 5 & 5 & 11.04 & 13.04 & 21.04 & 9.5 & 1 & 9 & $\begin{array}{l}\text { II dec. } \\
\text { VIII }\end{array}$ \\
\hline Yevraziya & 7 & 7 & 13.04 & 15.04 & 25.04 & 9.3 & 3 & 7 & e. VII \\
\hline
\end{tabular}

* Tree vigour-assessed on a 1-9-point rating scale: 1-very weak; 3-weak; 5-medium; 7-strong; 9-very strong; ${ }^{* *}$ Crown habit: 1-columnar; 3-upright; 5-conical; 7-spreading; 9-droopy; *** Productivity: 0-no fruiting; 1-very weak; 3-weak; 5-medium; 7-abundant; 9-very abundant. 


\subsection{Flowering}

In the Experimental Orchard at Dabrowice, the trees of the earliest Japanese plum cultivars began flowering in the first decade of April and ended flowering in the second decade of April (Table 2). Late cultivars started flowering in the second and ended in the third decade of April. In each year of the study, 'Barkhatnaya', 'Tsernushka Rannaya', 'Chuk', and 'Tatyana' trees bloomed at the earliest. In contrast, 'Yevraziya' trees were the last to bloom. Trees of most cultivars bloomed profusely. When compared to others, only trees of 'Formosa' and 'Herkules' cultivars bloomed less intensively. The length of flowering period depended on the year and cultivar and, in the years 2015-2020, it was, on average, from eight to 14.3 days. (Table 2). In general, the length of the flowering period of Japanese plum cultivars in Poland was similar to that in Serbia $[13,14]$.

\subsection{Yield and Ripening Time of Fruit}

Trees of twenty-two assessed cultivars started fruiting in the first year after planting, twelve cultivars started fruiting in the second year after planting, and two cultivars, 'Blue Gigant' and 'Yevraziya', in the third year after planting. Fruit set in individual cultivars in our experiment was varied, because, as a rule, early flowering of trees caused that the buds and flowers were damaged by late spring frost, which was also reported by Butac et al. [15] on the basis of studies carried out in Romania. The 'Barkhatnaja', 'Inese', 'Shater', 'Tatyana', and 'Vanier' trees were distinguished by regular, very high yields (Table 2). The following trees also yielded satisfactorily: 'Chuk', 'Dofi Sandra', 'Early Golden', 'Ewierch Rannyj', 'Gek', 'General', 'Kometa', 'Kometa Late', 'Maschenka', 'Naidyona', 'Tshernushka', and 'Yevraziya'. The yielding results of these cultivars are consistent with the results that were obtained by other authors $[13,14,16,17]$. The trees of the 'Formosa' cultivar had the lowest yields. Moreover, trees of the 'Black Diamond', 'Blue Gigant', and 'Herkules' cultivars yielded poorly and irregularly. In the available literature, there is no information on the yielding of 'Formosa', 'Blue Gigant', and 'Herkules' trees in the conditions of Central and Eastern Europe. Brooks and Olmo [18] report on the high productivity of 'Black Diamond' trees. However, this cultivar cannot be classified as abundantly yielding in the climatic conditions of Poland and Hungary [19].

The ripening date was constant during the evaluation period. The exception was 2018, when the weather conditions in the growing season meant that the fruit reached harvest maturity approximately two weeks earlier than in other years. Very early, already in the first decade of July, the fruit of 'Ewierch Rannyj', 'Gauota', 'Oishi Wase' 'Tsernushka', and 'Tsernushka Rannaya' cultivars reached maturity. The 'Angeleno' and 'Friar' cultivars were included in the group of the latest ones (Table 2). In the climatic conditions of central Poland, the fruits of most Japanese plum cultivars matured a few to several days later than in the conditions of Russia and Ukraine [16,17]. Additionally, the harvest of Japanese plum fruits in Poland takes place later when compared to Hungary [19], Iran [20], or Serbia $[13,14]$.

\subsection{Determination of Fruit Quality}

The mean fruit weight of the Japanese plum cultivars varied from year to year and it depended mainly on the weather conditions and yield. Among the thirty-six cultivars assessed, four cultivars were classified as small-fruited (20-25 g), 15 as medium (26-40 g), nine as large (41-55 g), two as large or very large (56-70 g), and six as very large (over $70 \mathrm{~g}$ ) (Table 3). The 'Chuk' and 'Inese' cultivars had the smallest fruits. 'Blue Gigant', 'Black Amber', and 'Herkules' trees produced the largest fruit. The fruit of most cultivars reached a size that was similar to that reported in the literature $[8,16-18,21]$. The exception was 'Early Golden' cultivar, which in research conducted in Iran by Pirkhezri et al. [20] had small fruit with low tree productivity. In Poland, the fruits of this cultivar were classified as medium to large in size, depending on the year, and the yielding of trees was high. 
Table 3. Fruit characteristics of 36 P. salicina cultivars (average, 2015-2020).

\begin{tabular}{|c|c|c|c|c|c|c|}
\hline Cultivar & $\begin{array}{l}\text { Mean Fruit } \\
\text { Weight [g] }\end{array}$ & Shape * & Skin Colour ** & Flesh Colour *** & $\begin{array}{c}\text { Soluble Solids } \\
{[\%]}\end{array}$ & $\begin{array}{l}\text { Stone Separating } \\
\text { from Flesh } * * * *\end{array}$ \\
\hline Angeleno & 57.3 de & 1 & 9 & $2 / 6$ & $14.3 \mathrm{c}-\mathrm{i}$ & 1 \\
\hline Barkhatnaya & $27.71-p$ & 2 & 9 & 2 & $14.0 \mathrm{~d}-\mathrm{j}$ & 7 \\
\hline Black Amber & $76.7 \mathrm{ab}$ & 2 & 11 & 2 & $13.9 \mathrm{~d}-\mathrm{k}$ & 1 \\
\hline Black Diamond & $72.1 \mathrm{bc}$ & 1 & 9 & 6 & $10.6 \mathrm{n}-\mathrm{o}$ & 1 \\
\hline Blue Gigant & $87.7 \mathrm{a}$ & 5 & 11 & 6 & $11.7 \mathrm{~m}-\mathrm{n}$ & 1 \\
\hline Chuk & $21.0 \mathrm{p}$ & 2 & 8 & 2 & $17.8 \mathrm{a}$ & 1 \\
\hline $\begin{array}{l}\text { Desertnaya } \\
\text { Rannaya }\end{array}$ & $42.0 \mathrm{f}-\mathrm{j}$ & 1 & 8 & $2 / 6$ & $12.9 \mathrm{~h}-1$ & 1 \\
\hline Dofi Sandra & $39.0 \mathrm{f}-1$ & 4 & 10 & 2 & $14.8 \mathrm{c}-\mathrm{g}$ & 1 \\
\hline Early Golden & $41.3 \mathrm{f}-\mathrm{k}$ & 2 & 4 & 2 & $12.4 \mathrm{j}-\mathrm{m}$ & 3 \\
\hline Ewierch Rannyj & $29.8 \mathrm{j}-\mathrm{p}$ & 2 & 9 & $2 / 6$ & $15.5 \mathrm{~b}-\mathrm{e}$ & 1 \\
\hline Friar & $64.1 \mathrm{~cd}$ & 1 & 11 & 2 & $13.2 \mathrm{~g}-\mathrm{m}$ & 1 \\
\hline Formosa & $51.4 \mathrm{ef}$ & 5 & 6 & 2 & $13.5 \mathrm{f}-\mathrm{m}$ & 1 \\
\hline Gauota & 46.6 efg & 2 & 6 & 2 & $12.4 \mathrm{j}-\mathrm{m}$ & 5 \\
\hline Gek & $28.3 \mathrm{k}-\mathrm{p}$ & 4 & 4 & 2 & $13.6 \mathrm{f}-1$ & 5 \\
\hline General & 51.8 ef & 5 & 8 & $2 / 6$ & $13.0 \mathrm{~g}-\mathrm{m}$ & 1 \\
\hline Herkules & $78.8 \mathrm{ab}$ & 2 & 6 & 2 & $12,6 \mathrm{i}-\mathrm{m}$ & 1 \\
\hline Inese & $21.3 \mathrm{p}$ & 4 & 6 & 2 & $15.1 \mathrm{c}-\mathrm{f}$ & 1 \\
\hline Kometa & $35.2 \mathrm{~g}-\mathrm{o}$ & 2 & 6 & 2 & $11.81-n$ & 1 \\
\hline Kometa Late & $36.6 \mathrm{~g}-\mathrm{m}$ & 5 & 8 & $2 / 6$ & $12.1 \mathrm{k}-\mathrm{n}$ & 3 \\
\hline Maschenka & $24.0 \mathrm{n}-\mathrm{p}$ & 2 & 6 & $2 / 6$ & $13.5 \mathrm{f}-\mathrm{m}$ & 1 \\
\hline Naidyona & $36.1 \mathrm{~g}-\mathrm{n}$ & 2 & 6 & 2 & $13.9 \mathrm{~d}-\mathrm{k}$ & 1 \\
\hline Obilnaya & $43.4 \mathrm{f}-\mathrm{i}$ & 2 & 9 & $2 / 6$ & $13.6 \mathrm{f}-1$ & 7 \\
\hline Oishi Wase & 49.7 ef & 5 & 6 & 2 & $16.0 \mathrm{bc}$ & 1 \\
\hline Ozark Premier & $73.2 \mathrm{bc}$ & 2 & 8 & 2 & $15.7 \mathrm{bcd}$ & 5 \\
\hline Puteshestvennitsa & $27.91-\mathrm{p}$ & 4 & 8 & $2 / 6$ & $17.0 \mathrm{ab}$ & 1 \\
\hline Santa Rosa & $44.1 \mathrm{fgh}$ & 5 & 9 & 6 & $15.2 \mathrm{c}-\mathrm{f}$ & 1 \\
\hline Shater & $28.01-\mathrm{p}$ & 4 & 10 & 2 & $9.7 \mathrm{o}$ & 5 \\
\hline Shiro & $35.2 \mathrm{~g}-\mathrm{O}$ & 5 & 4 & 2 & $13.0 \mathrm{~g}-\mathrm{m}$ & 1 \\
\hline Skoroplodnaya & $26.71-p$ & 2 & $5 / 6$ & 2 & 9.60 & 5 \\
\hline Slivovidnaya & $23.2 n-p$ & 2 & 8 & 2 & $13.7 \mathrm{e}-\mathrm{k}$ & 9 \\
\hline Superior & $75.8 \mathrm{bc}$ & 5 & 8 & 2 & $15.7 \mathrm{bcd}$ & 1 \\
\hline Tatyana & $32.2 \mathrm{~h}-\mathrm{p}$ & 1 & 6 & 2 & $14.7 \mathrm{c}-\mathrm{h}$ & 3 \\
\hline Tsernushka & $22.5 \mathrm{o}-\mathrm{p}$ & 2 & 8 & 2 & $15.9 \mathrm{bc}$ & 1 \\
\hline $\begin{array}{l}\text { Tsernushka } \\
\text { Rannaya }\end{array}$ & $25.91-p$ & 2 & 8 & 2 & $15.1 \mathrm{c}-\mathrm{f}$ & 1 \\
\hline Vanier & $51.9 \mathrm{ef}$ & 2 & 3 & 2 & $14.0 \mathrm{~d}-\mathrm{j}$ & 1 \\
\hline Yevraziya & $30.8 \mathrm{i}-\mathrm{p}$ & 2 & 10 & 2 & $15.2 \mathrm{c}-\mathrm{f}$ & 5 \\
\hline
\end{tabular}

Means separation within columns by Duncan's test at significance level $p=0.05$; the means marked with the same letter do not differ significantly. * Shape: 1-oblate; 2-circular; 3-elliptic; 4-oval; 5-cordate; 6-oblong; 7-ovate; 8-bottle-like; ${ }^{* *}$ Skin colour: 1-greenish white; 2-green; 3-yellowish green; 4-yellow; 5-orange yellow; 6-red; 7-light violet; 8-purplish violet; 9-dark violet; 10-violet blue; 11-dark blue; *** Flesh colour: 1-whitish; 2-green; 3-yellowish green; 4-yellow; 5-orange; 6-red; *** Stone separating from flesh: 1-very week (adherent); 3-week; 5-medium; 7-good; 9-very good (non -adherent). 
The most numerous group among the studied cultivars were those with round fruits (18 out of 36 assessed) (Table 3). The fruits of five cultivars were round, but flattened at the tops, eight were heart-shaped, and the other five were oval. The skin of half of the cultivars tested was dark with various shades of purple, eleven cultivars had red skin, and three-dark blue (Table 3). Three cultivars: 'Early Golden', 'Gek', and 'Shiro' were covered with a yellow skin, rarely found in plums. Among the tested cultivars, the fruit of twenty-five cultivars had a yellow flesh color. The 'Black Diamond', 'Blue Gigant', and 'Santa Rosa' cultivars had red flesh, and the flesh of the other eight cultivars was yellow-red in color (Table 3).

An important quality parameter of plum fruit is Total Soluble Solids content, which largely determines the fruit's flavor. This is a cultivar feature, but it also depends on the intensity of fruiting of trees and climatic conditions. Vangdal et al. [22] found a negative correlation between the productivity of trees and quality of plum fruit. Our own results confirm this relationship. In some years, the trees of many Japanese plum cultivars yielded abundantly, which had an adverse effect on the size and taste of plums. An example is 2016, when trees yielded abundantly, but the fruit size and Total Soluble Solids content were lower than in the rest of research years. Total Soluble Solids content of $18-20 \%$ almost always guarantees a good taste for plums, according to Kemp and Wustenberghs [23]. In Polish growing conditions, the fruits of cultivars tested contained less sugars, i.e., from $9.6 \%$ in the case of 'Skoroplodnaya' cultivar to $17.8 \%$ in the case of 'Chuk' cultivar (Table 3). However, the taste is determined not only by the sugar content in fruit, but also by other characteristics, such as acid content and, in particular, by the sugar-acid ratio. That is why 'Formosa', 'Oishi Wase', and 'Ozark Premier' cultivars had delicious fruit every year. Unfortunately, the climatic conditions in Poland are not conducive to such accumulation of Total Soluble Solids in Japanese plum fruit, such as in Romania [15], Serbia [13,14], or Iran [20].

The dessert fruit, in addition to its attractive appearance and delicious taste, good separation of stone from flesh is essential. In our research, stone was the easiest to separate from flesh in fruit of 'Slivovidnaya' cultivar (Table 3). However, as many as twenty-four cultivars had seeds that were firmly attached to flesh, regardless of the year of study. The results of our research are partially consistent with those obtained by other authors [16-18,21]. Contrary to results obtained in Poland, Pirkhezri et al. [20] report a very good separation of stone from flesh in fruit of 'Angeleno' cultivar. These differences may be caused by climatic conditions that are not favorable for ripening of this cultivar in Poland.

\subsection{Ploidy Level}

For the 2C DNA reference diploid cultivar 'Santa Rosa', the position of the 2C DNA fluorescence peak of the $X$ axis on the FCM histogram was determined to be $51.3 \pm 1.89$, and 2C DNA peak for haxaploid 'Eruni' was $151.3 \pm 2.66$ (Figure 1). Among the studied genotypes, 31 genotypes with the peak values on $X$ axis ranging between $50.3 \pm 1.66$ (recorded for 'Puteshestvennitsa') and $54.2 \pm 1.78$ (for 'Dofi Sandra') (on average, $52.1 \pm 2.44$ ) were evaluated with high probability as diploids (Table 4). 'Herkules' was evaluated to be pentaploid as its peak position was $122.5 \pm 1.49$ and 'Yevraziya' was presumably aneuploid, showing nearly hexaploidy with probably a few chromosomes missing; its peak position was $139.1 \pm 2.06$. However, the aneuploidy of this cultivar should be confirmed in further studies by the microscopic analysis of the chromosome number. 


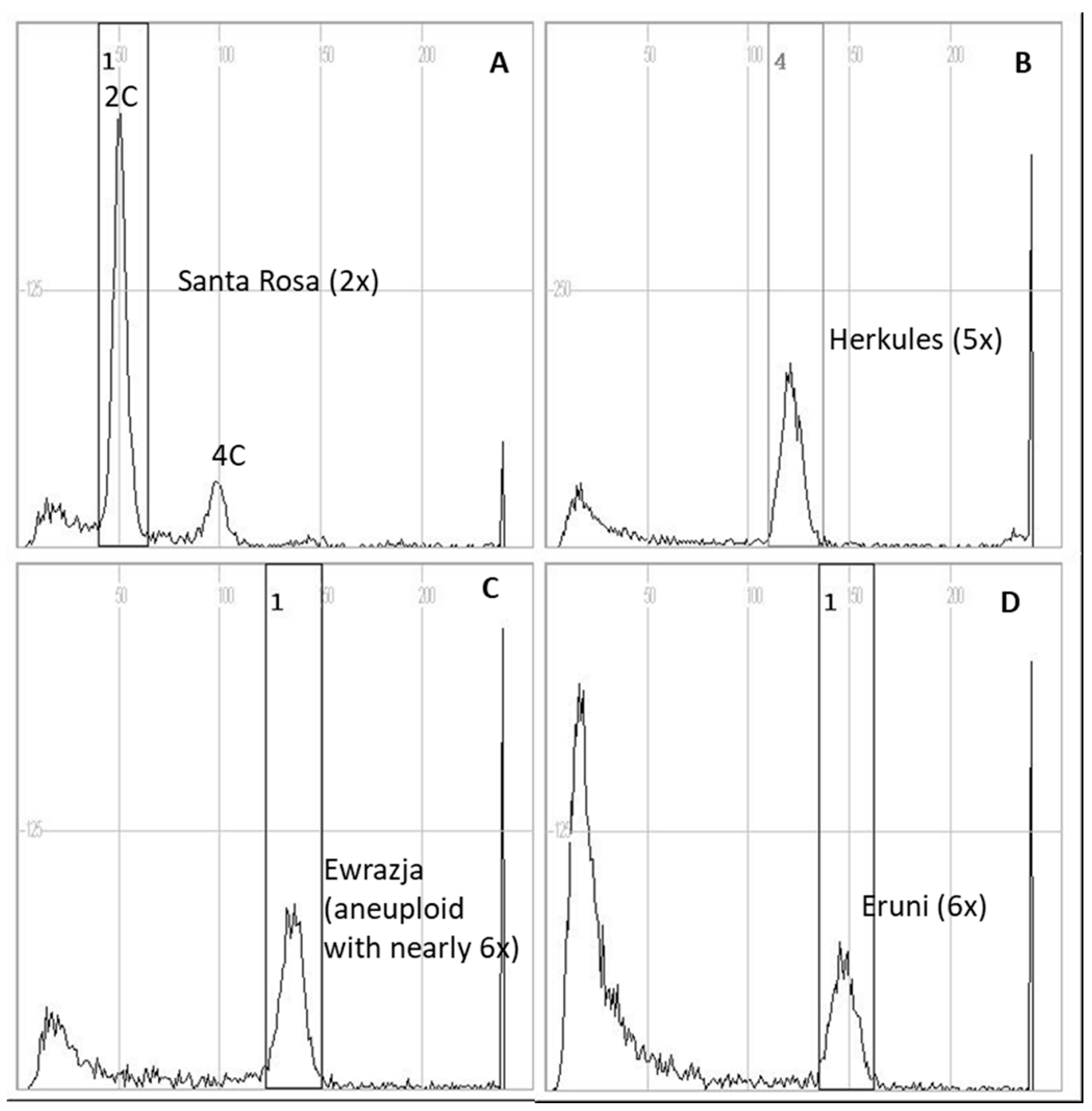

Figure 1. Histograms of ploidy level estimation of Japanese plum cultivars using flow cytometry (FCM): (A) external standard diploid cultivar 'Santa Rosa'; (B) pentaploid 'Herkules'; and, (C) aneuploid showing nearly hexaploidy 'Yevrazija', and (D) reference hexaploid 'Eruni'.

Genotypes of higher ploidy levels pentaploid 'Herkules' and putative aneuploid hexaploid 'Yevraziya' are characterized with the latest date of flowering. This phenomenon of delayed flowering of polyploids within species is often observed [24]. It was reported inter alia for autotetraploids of Malus $\times$ domestica [25], Gerbera jamesonii [26], and Dendranthema nankingense [27].

It is generally acceptable that the natural polyploid formation within the genus Prunus results from both somatic chromosome doubling and union of unreduced gametes with the latter considered to be the most important polyploidisation mechanism [28,29]. The pentaploid 'Herkules' is hybrid of hexaploid P. domestica 'Ontario' and diploid P. salicina 'Formosa', and its pentaploidy results from pollination with unreduced pollen (2n) of 'Formosa' [30,31]. 
Table 4. Ploidy level evaluation of P. salicina cultivars using flow cytometry analysis.

\begin{tabular}{|c|c|c|c|c|c|}
\hline No. & Cultivar & Ploidy Level & No. & Cultivar & Ploidy Level \\
\hline 1 & Angeleno & $2 \times$ & 19 & Kometa Late & $2 \times$ \\
\hline 2 & Barkhatnaya * & - & 20 & Maschenka & $2 \times$ \\
\hline 3 & Black Amber & $2 \times$ & 21 & Naidyona & $2 \times$ \\
\hline 4 & Black Diamond & $2 \times$ & 22 & Obilnaya & $2 \times$ \\
\hline 5 & Blue Gigant & $2 \times$ & 23 & Oishi Wase & $2 \times$ \\
\hline 6 & Chuk & $2 \times$ & 24 & Ozark Premier & $2 \times$ \\
\hline 7 & Desertnaya Rannaya & $2 \times$ & 25 & Puteshestvennitsa & $2 \times$ \\
\hline 8 & Dofi Sandra & $2 \times$ & 26 & Santa Rosa & $2 \times$ \\
\hline 9 & Early Golden & $2 \times$ & 27 & Shiro & $2 \times$ \\
\hline 10 & Ewierch Rannyj & $2 \times$ & 28 & Shater* & - \\
\hline 11 & Friar & $2 \times$ & 29 & Skoroplodnaya & $2 \times$ \\
\hline 12 & Formosa & $2 \times$ & 30 & Slivovidnaya & $2 \times$ \\
\hline 13 & Gauota & $2 \times$ & 31 & Superior & $2 \times$ \\
\hline 14 & Gek & $2 \times$ & 32 & Tatyana * & - \\
\hline 15 & General & $2 \times$ & 33 & Tsernushka & $2 \times$ \\
\hline 16 & Herkules & $5 \times$ & 34 & Tsernushka Rannaya & $2 \times$ \\
\hline 17 & Inese & $2 \times$ & 35 & Vanier & $2 \times$ \\
\hline 18 & Kometa & $2 \times$ & 36 & Yevraziya & $6 \times$ aneuploid \\
\hline
\end{tabular}

* Cultivars not analyzed for ploidy level because trees were destroyed due to infection by the Plum pox virus (PPV) causing sharka disease.

\section{Materials and Methods}

\subsection{Location and Plant Material}

Research work was conducted in 2015-2020 based on the field experiment that was located at Experimental Orchard in Dabrowice (central Poland-latitude $145 \mathrm{~m}, 51^{\circ} 54^{\prime \prime} \mathrm{N} / 20^{\circ} 06^{\prime \prime} \mathrm{E}$ ). The 36 Japanese plum cultivars were evaluated (Table 5).

Table 5. List and information on plum cultivars studied. Source: $[1,8,16-18,21,32]$.

\begin{tabular}{|c|c|c|c|}
\hline No. & Cultivar & Reported Parentage & Country \\
\hline 1 & Angeleno & Selection within a population of seedlings resulted from open pollination & USA \\
\hline 2 & Barkhatnaya & unknown & Ukraine \\
\hline 3 & Black Amber & Friar $\times$ Queen Rosa & USA \\
\hline 4 & Black Diamond & Angeleno $\times$ open pollination & England \\
\hline 5 & Blue Gigant & No date & No date \\
\hline 6 & Chuk & P. salicina $\times$ P.cerasifera $($ Skoroplodnaya $\times$ Otlichnitsa) & Russia \\
\hline 7 & Desertnaya Rannaya & Wickson $\times$ P.cerasifera Tavricheskaya & Ukraine \\
\hline 8 & Dofi Sandra & Black Gold $\times$ Burmosa & Italy \\
\hline 9 & Early Golden & A changce seedling of Burbank or Shiro & Canada \\
\hline 10 & Ewierch Rannyj & No date & Ukraine \\
\hline 11 & Friar & Gaviota $\times$ Nubiana & USA \\
\hline 12 & Formosa & unknown & USA \\
\hline 13 & Gauota & unknown & Russia \\
\hline
\end{tabular}


Table 5. Cont.

\begin{tabular}{|c|c|c|c|}
\hline No. & Cultivar & Reported Parentage & Country \\
\hline 14 & Gek & Skoroplodnaya $\times$ P.cerasifera Otlichnitsa & Russia \\
\hline 15 & General & Obilnaya $\times$ open pollination & Ukraine \\
\hline 16 & Herkules & Ontario $\times$ Formosa & Sweden \\
\hline 17 & Inese & Seedling of breeding number PU-16807 & Latvia \\
\hline 18 & Kometa & P. salicina $\times$ P.cerasifera $($ Skoroplodnaya $\times$ Pionerka) & Russia \\
\hline 19 & Kometa Late & Kubanska Kometa $\times$ open pollination & Russia \\
\hline 20 & Maschenka & No date & Ukraine \\
\hline 21 & Naidyona & P. salicina $\times$ P.cerasifera $($ Skoroplodnaya $\times$ Desertnaya) & Belarus \\
\hline 22 & Obilnaya & P. salicina $\times$ P.cerasifera $($ Berbank $\times$ Tavricheskaya) & Ukraine \\
\hline 23 & Oishi Wase & No date & No date \\
\hline 24 & Ozark Premier & Burbank $\times$ Methly & USA \\
\hline 25 & Puteshestvennitsa & P. salicina $\times$ P.cerasifera (seedling of cultivar Desertnaya) & Russia \\
\hline 26 & Santa Rosa & P. salicina $\times$ P.simonii $\times$ P.americana & USA \\
\hline 27 & Shater & Fibing $\times$ open pollination & Russia \\
\hline 28 & Shiro & A chance seedling & USA \\
\hline 29 & Skoroplodnaya & P. salicina $\times$ P.ussuriensis Ussuriyskaya Krasnaya $\times$ Klaymeks & Russia \\
\hline 30 & Slivovidnaya & Obilnaya $\mathrm{x}$ open pollination & Ukraine \\
\hline 31 & Superior & P. salicina Burbank $\times($ P. americana $\times$ P. simonii $)$ Kaga & USA \\
\hline 32 & Tatyana & No date & Ukraine \\
\hline 33 & Tsernushka & No date & Ukraine \\
\hline 34 & Tsernushka Rannaya & No date & Ukraine \\
\hline 35 & Vanier & Burbank $\times$ Wickson & Canada \\
\hline 36 & Yevraziya & Lakrescent $\times$ open pollination & Russia \\
\hline
\end{tabular}

One-year-trees of Japanese plum cultivars (Prunus salicina Lindl.), grafted onto 'Wangenheim Prune' seedling rootstocks, were planted in the spring of 2013, with a spacing of $4.7 \mathrm{~m} \times 3 \mathrm{~m}$, in a grey-brown podzolic soil. Each cultivar was represented by three freestanding trees. In the first two years after planting, the soil was kept free from weeds by mechanical cultivation. During the following years, soil management included frequent grass mowing in the alleyways and maintenance of $1 \mathrm{~m}$ wide herbicide strips along the tree rows. The experimental orchard was irrigated with a drip system. Fertility, pest, and disease control were carried out in accordance with the current recommendations for commercial plum orchards and the principles of integrated fruit production.

\subsection{Weather Conditions}

Every year, data on weather conditions were collected through the meteorological station that was located at the Experimental Orchard in Dabrowice. The collected climatic data were used to assess their impact on health condition and yield of trees, as well as on fruit quality. In the years of research, the average annual rainfall in this area was $446 \mathrm{~mm}$, and the average annual temperature was $9.6^{\circ} \mathrm{C}$. Table 6 presents basic meteorological data for the period 2015-2020. 
Table 6. Annual temperatures and precipitation at the Experimental Orchard in Dabrowice in 2015-2020.

\begin{tabular}{ccccc}
\hline \multirow{2}{*}{ Year } & \multicolumn{3}{c}{ Temperature $\left[{ }^{\circ} \mathbf{C}\right]$} & Precipitation $[\mathbf{m m}]$ \\
\cline { 2 - 5 } & Minimum & Maximum & Mean & Total \\
\hline 2015 & -11.4 & 37.9 & 9.9 & 384.0 \\
\hline 2016 & -17.9 & 34.2 & 9.3 & 503.8 \\
\hline 2017 & -20.9 & 37.4 & 9.0 & 564.0 \\
\hline 2018 & -20.6 & 35.5 & 9.7 & 364.2 \\
\hline 2019 & -11.5 & 39.0 & 10.6 & 359.7 \\
\hline 2020 & -10.1 & 35.9 & 9.3 & 499.4 \\
\hline
\end{tabular}

\subsection{Tree Growth and Productivity Assessment}

In 2015-2020, the following parameters were assessed:

a. Frost damage to trees-assessed on a 1-9-point rating scale according to Perczak [33].

b. Plum pox virus (sharka) symptoms - on the basis of inspection performed at the end of June and in the middle of September. The state of trees was determined visually on a $0-3$ point rating scale for symptoms on the leaves. The symptoms of the fruit were investigated, when the fruit consumption maturity was reached on a 0-3 point rating scale according to Iliev and Stoev [34].

c. $\quad$ Tree vigor and canopy shape assessed on a 1-9 point rating scale.

d. Flowering time - was recorded by recommendations of the international working group for pollination: start of flowering-10\% open flowers; full bloom- $80 \%$ of the flower buds on the tree had reached the open flower stage; and, end of flowering-90\% of the petal fall [35].

\subsection{Determination of Fruit Quality}

The evaluation of the fruit of each genotype was determined in each year of the study using five samples of 20 randomly picked ripe fruits. The subject of the research was the mean fruit weight and shape of fruit, skin and flesh color, as well as Total Soluble Solids content in fruit (using the ATAGO PR-101 electronic refractometer, Atago Co., Ltd., Tokyo, Japan).

The evaluation of cultivars in terms of pomological traits was made according to the Plum descriptor that was developed by UPOV (International Union for the Protection of New Varieties Cultivars of Plants).

\subsection{Ploidy Level}

Analysis of ploidy level was performed in 2020 using flow cytometry analysis (FCM). Young leaf samples were randomly collected from two plants of each genotype. Leaf tissue $\left(0.25-0.5 \mathrm{~cm}^{2}\right)$ was chopped in a Petri dish in $0.75 \mathrm{~mL}$ nuclei isolation Partec buffer (Sysmex Partec GmbH, Münster, Germany) to which $50 \mu \mathrm{g} \mathrm{mL}^{-1} 4^{\prime}$,6-diamidino-2-phenylindole (DAPI) and 1\% polyvinylpyrrolidone (PVP) were added. After adding $0.75 \mathrm{~mL}$ of the isolation buffer, the samples were filtered through a $30 \mu \mathrm{m}$ filter and then incubated for 45-60 min. in darkness at room temperature. The fluorescence of the nuclei was measured using ploidy analyser CyFlow Ploidy (Sysmex Partec GmbH, Münster, Germany) with UV-LED $365 \mathrm{~nm}$. The data were analyzed by means of software CyView (Sysmex Partec $\mathrm{GmbH}$, Münster, Germany). Samples with at least 2000 nuclei were measured for two leaves of each plant. As external standard of known ploidy levels, diploid cultivar 'Santa Rosa' [5] and hexaploid P. domestica 'Eruni' were used [7].

\subsection{Statistical Analysis}

The obtained results concerning the morphological features of trees are presented numerically in tables. The results of measurements of fruit weight and Total Soluble Solids 
content were processed using one-way statistical analysis of variance in the Statistica 10 program. The Duncan's multiple range test was employed at $p=0.05$ to evaluate the significance of the differences between means.

\section{Conclusions}

The conducted research showed a large diversity of genotypes in the analyzed Japanese plum population. The Japanese plum cultivars differ in terms of tree vigor, frost resistance, susceptibility to sharka, flowering time and intensity, yielding, fruit maturity date, and fruit quality characteristics. Based on the assessment of tree productivity, it can be concluded that 'Barkhatnaya', 'Inese', 'Shater', 'Tatyana', and 'Vanier' cultivars are the best for cultivation in the climate of Central Europe. 'Chuk', 'Dofi Sandra', 'Early Golden', 'Ewierch Rannyj', 'Gek', 'General', 'Kometa', 'Kometa Late', 'Maschenka', 'Naidyona', 'Tsernushka', and 'Yevraziya' trees were also very productive. The 'Barkhatnaya' and 'Tatyana' cultivars turned out to be very susceptible to sharka, and recommending them for commercial cultivation is very risky. Except for pentaploid 'Herkules' and aneuploid (nearly hexaploid) 'Yevraziya' cultivars, the remaining Japanese plum cultivars turned out to be diploids.

Author Contributions: Conceptualization, M.S. and A.G.; methodology, M.S. and M.P.; validation, M.S., M.P. and E.R.; formal analysis, M.S. and M.P.; investigation, A.G. and M.P.; resources, A.G.; data curation, A.G.; writing—original draft preparation, A.G.; writing—review and editing, M.S. and M.P.; visualization, A.G. and E.R.; supervision, M.S. and A.G.; project administration, M.S.; funding acquisition, M.S. All authors have read and agreed to the published version of the manuscript.

Funding: This research was funded by the Polish Ministry of Agriculture and Rural Development in the frame of programme on protection of genetic resources of horticultural crops.

Institutional Review Board Statement: Not applicable.

Informed Consent Statement: Not applicable.

Data Availability Statement: Not applicable.

Conflicts of Interest: The authors declare no conflict of interest.

\section{References}

1. Blazek, J. A survey of the Genetic Resources used in Plum Breeding. Acta Hortic. 2007, 734, 31-45. [CrossRef]

2. Topp, B.L.; Russell, D.M.; Neumüller, M.; Dalbo, M.A.; Liu, W. Plum. In Fruit Breeding; Chapter 15; Badenes, M.L., Byrne, D.H., Eds.; Springer: Berlin/Heidelberg, Germany, 2012; pp. 571-621.

3. Okie, W.R.; Hancock, J.F. Plums. In Temperate Fruit Crop Breeding: Germplasm to Genomics; Hancock, J.F., Ed.; Springer: New York, NY, USA, 2008; pp. 337-357.

4. Das, B.; Ahmed, N.; Singh, P. Prunus Diversity-Early and Present Development: A Review. Int. J. Biodivers. Conserv. 2011, 3, 721-734. [CrossRef]

5. Ben Tamarzizt, H.; Walker, D.; Ben Mustapha, S.; Abdallah, D.; Baraket, G.; Salhi Hannachi, A.; Zehdi Azzouzi, S. DNA Variation and Polymorphism in Tunisian Plum Species (Prunus spp.): Contribution of Flow Cytometry and Molecular Markers. Genet. Mol. Res. 2015, 14, 18034-18046. [CrossRef]

6. Prunus Crop Germplasm Committee. Prunus Vulnerability Statement. 2017; pp. 1-13. Available online: https:/ /www.ars-grin. gov/npgs/cgc_reports/prunusvuln2017.pdf (accessed on 26 April 2021).

7. Podwyszyńska, M.; Sitarek, M.; Marasek-Ciołakowska, A.; Kowalska, U. Nuclear DNA Content and Phenotypic Traits of the Prunus Rootstocks from Poland's Gene Resources. Zemdirb. Agric. 2020, 107, 71-78. [CrossRef]

8. Grzyb, Z.S.; Rozpara, E. Intensywny Sad Śliwowy; Hortpress: Warszawa, Poland, 2007; pp. 5-214.

9. Grzyb, Z.S.; Rozpara, E. Klasyfikacja Niektórych Odmian Śliwy Pod Względem Wielkości Owoców i Terminu Dojrzewania. Zesz. Probl. Postępów Nauk Rol. 2007, 517, 331-337.

10. Hartmann, W.; Neumüller, M. Plum Breeding Plantation Tree Crops: Temperate Species; Jain, S.M., Priyadaeshan, P.M., Eds.; Springer: Berlin/Heidelberg, Germany, 2009; pp. 161-231.

11. Grzyb, Z.S.; Rozpara, E. Plum Production in Poland. Acta Hortic. 1998, 478, 19-24. [CrossRef]

12. Malinowski, T.; Rozpara, E.; Grzyb, Z.S. Evaluation of the Susceptibility of Several Plum (Prunus domestica L.) Cultivars to Plum Pox Virus (PPV) Infection in the Field. Sharka-Like Symptoms Observed on 'Jojo' Fruit are not Related to PPV. J. Hortic. Res. 2013, 21, 61-65. [CrossRef] 
13. Milatović, D.; Durović, D.; Dorđević, B. Evaluation of Japanese Plum Cultivars in Serbia. Acta Hortic. 2013, 981, 173-176. [CrossRef]

14. Milatović, D.; Durović, D.; Zec, G.; Radović, A. Evaluation of Some Diploid Plum Cultivars in the Region of Belgrade. Acta Hortic. 2019, 1260, 153-158. [CrossRef]

15. Butac, M.; Militaru, E.; Chitu, E.; Plopa, C.; Sumedrea, M.; Sumedrea, D. Differences and Similarities between some European and Japanese Plum Cultivars. Acta Hortic. 2019, 1260, 129-136. [CrossRef]

16. Isaczkin, A.W.; Worobiew, B.N. Sortowoj Katalog Płodowych Kultur Rossii. Śliwa. AST Actrel. Moskwa 2003, 427, $293-369$.

17. Pawliuk, W.W. Pomologia. Śliwa, Wiśnia, Czereśnia. Kijezw 2004, 4, 7-104.

18. Brooks, R.M.; Olmo, H.P. Register of New Fruit and Nut Varieties 1920-1950; University of California Press: Berkely, CA, USA; Cambridge University Press: Cambridge, UK, 1952; pp. 7-50.

19. Szabo, Z.; Nyeki, J. Japanese Plums in Hungary. Acta Hortic. 2002, 577, 65-72. [CrossRef]

20. Pirkhezri, M.; Fatahi Mogagam, M.R.; Edabi, E.; Hassani, D.; Abdoosi, V. Morphological Study of Some New Japanese Plum (Prunus Salicina Lindl.) Cultivars Grown in Iran. Int. J. Biosci. 2014, 5, 180-187.

21. Karklins, J.; Skrivele, M.; Kaufmane, E.; Ikase, L. Plumju Skirnes. Latvijas Pomologija; Mintis: Ithaca, NY, USA, 2007 ; pp. 3-204.

22. Vangdal, E.; Flatland, S.; Nordbo, R. Fruit Quality Changes during Marketing of New Plum Cultivars (Prunus Domestica L.). Hortic. Sci. 2007, 34, 91-95. [CrossRef]

23. Kemp, H.; Wustenberghs, H. Screening of Plums and Prunes for Fresh Consumption, 1988-1997. Acta Hortic. 1998, 478, 207-216. [CrossRef]

24. Mayfield, D.; Chen, Z.J.; Pires, J.C. Epigenetic Regulation of Flowering Time in Polyploids. Curr. Opin. Plant Biol. 2011, 14, 174-178. [CrossRef]

25. Xue, H.; Zhang, B.; Tian, J.R.; Chen, M.M.; Zhang, Y.Y.; Zhang, Z.H.; Ma, Y. Comparison of the Morphology, Growth and Development of Diploid and Autotetraploid 'Hanfu' Apple Trees. Sci. Hortic. 2017, 225, 277-285. [CrossRef]

26. Gantait, S.; Mandal, N.; Bhattacharyya, S.; Das, P.K. Induction and Identification of Tetraploids Using in vitro Colchicine Treatment of Gerbera jamesonii Bolus Cv. Sciella. Plant Cell Tissue Organ Cult. 2011, 106, 485-493. [CrossRef]

27. Liu, S.; Chen, S.; Chen, Y.; Guan, Z.; Yin, D.; Chen, F. In vitro Induced Tetraploid of Dendranthema Nankingense (Nakai) Tzvel. Shows an Improved Level of Abiotic Stress Tolerance. Sci. Hortic. 2011, 127, 411-419. [CrossRef]

28. Ramsey, J.; Schemske, D.W. Pathways, Mechanisms, and Rates of Polyploid Formation in Flowering Plants. Annu. Rev. Ecol. Syst. 1998, 29, 467-501. [CrossRef]

29. Wang, Y.; Du, H.M.; Zhang, J.; Chen, T.; Chen, Q.; Tang, H.R.; Wang, X.R. Ploidy Level of Chinese Cherry (Cerasus Pseudocerasus Lindl.) and Comparative Study on Karyotypes with Four Cerasus Species. Sci. Hortic. 2018, 232, 46-51. [CrossRef]

30. Neumüller, M. Fundamental and Applied Aspects of Plum (Prunus domestica) Breeding. Fruit Veg. Cereal Sci. Biotechnol. 2011, 139-156. Available online: www.globalsciencebooks.info (accessed on 26 April 2021).

31. Guerra, M.E.; Rodrigo, J. Japanese Plum Pollination: A Review. Sci. Hortic. 2017, 197, 674-686. [CrossRef]

32. Hjalmarsson, I. Plum Cultivars in Sweden:m History and Conservation for Future Use. Proc. Latv. Acad. Sci. Sect. B 2019, 73, 207-213. [CrossRef]

33. Perczak, J. Metodyka Badania Wartości Gospodarczej Odmian (WGO), Odrębności, Wyrównania I Trwałości (OWT) Roślin Uprawnych. Śliwa COBORU Stupia Wielka 2006, I, 1-33.

34. Iliev, P.; Stoev, A. Reaction of Some Plum Cultivars to Sharka Virus (Plum pox Virus, PPP-M Strain). Acta Hortic. 2002, 577, 73-77. [CrossRef]

35. Wertheim, S.J. Methods for Cross Pollination and Flowering Assessment and their Interpretation. Acta Hortic. 1996, 423, 237-242. [CrossRef] 